\title{
Relationship between Soil Health Assessment and the Growth of Lettuce
}

\author{
Riwandi and Merakati Handajaningsih \\ Department of Agroecotechnology, Agriculture Faculty University of Bengkulu, Jl. WR. Supratman \\ Bengkulu.Phone/Fax 0736 21290,e-mail: riwandi_unib@yahoo.co.id
}

Received 15 October 2010 / accepted 5 January 2011

\begin{abstract}
Soil health is very important point for plant growth which is measured by several indicators. The purposes of the research were to assess and to classify soil health Padang Betuah area of Bengkulu, and to compare between soil health indicators and lettuce plant performance indicators. Soils, consist of mineral and peat soils, were sampled using a soil random sampling technique. Lettuce plants were grown in polybags using sample soils. Both lettuce performance and soil health were assessed by calculating the percentage of total scores of lettuce plant or soil performance indicators which derived from variables observed. Soil variables for field evaluation included color, moisture content, texture, structure, compaction, land slope, organic matter, $\mathrm{pH}$, amount of earthworm, erosion level, LCC (Legume Cover Crop), and vegetation performance. Soil variables for laboratory evaluation were $\mathrm{pH}$, electrical conductivity (EC), total Carbon and Nitrogen, available-Posphorus, cation exchangeable capacity, base saturation, and aluminum saturation. While, the variables for lettuce growth performance included plant height, numbers of leaf, degree of leaf greenness, plant fresh weight, and relative percentage of shoot : root ratio. The results of field and laboratory evaluation showed that soil health were categoried as a healthy soil and moderate healthy soil both for mineral and peat soils, respectively. Furthermore, similar categories were also obtained for evaluation of plant performance categories. No correlation was found between the soil performance indicator category and the lettuce performance category.
\end{abstract}

Keywords: Field indicator, laboratory indicator, lettuce growth indicator, soil health

\section{INTRODUCTION}

Soil is an important factor to increase agricultural production, to keep and to attain water health and quality, as well as a home of various organisms, and as a filter and neutralizer of poisoning substances (NRCS 1996, Riwandi 2007). Therefore, maintaning soil health is very important in order to sustain the soil function.

Soil health is an integration and optimalization among various soil physical, chemical, and biological properties, the condition of which would increase productivity and quality of plant, soil, and environment (Idowu et al. 2008; Gugino et al. 2007). Soil health is a combination and an optimum of soil properties to increase quality and productivity of soil, plant, and environment. Soil health is the capability of soil to perform the productivity without depleting environment quality in the future.

J Trop Soils, Vol. 16, No. 1, 2011: 25-32

ISSN 0852-257X
Soil health assessment is obtained based on soil performance indicators, that is a measureable soil properties and it gives signs that soil does its function naturally. Soil will function as it is whenever the interaction between one property and the others give a mutualistic synergy both to the soil health and quality. For example, soil with an amount of organic matter will be able to ameliorate $\mathrm{Al}$ effect by chelating $\mathrm{Al}$ to the organic matter (Hocking 2001).

This soil will also serve the essensial elements for plant growth and development, soil moisture content as well as it will creates a healthy environment for plant growth and soil microorganisms. The proper interactions among physical, chemical, and biological properties will perform healthy soil and finally it will provide healthy plants.

The urgency of this research is that soil as natural source has been contaminated with many pollutants because of human activities in agriculture (the usage of syntetic fertilizers and pesticides, and mismanagement of soil). This assumption should be proven. To the farmers, this research was 
expected to help them to choose the healthy soil of the agricultural land sites and decide which piece of land the most fit to grow their plants. Growing plants on the healthy soil can decrease production costs and have better harvesting products. The objectives of this research were: 1) to assess soil health using soil performance indicators, 2) to classify soil health, and 3) to correlate between the lettuce plant growth and the soil health.

\section{MATERIALS AND METHODS}

\section{Study Site}

Research was conducted from April to July 2009 in Padang Betuah, Pondok Kelapa District, Central Bengkulu, Indonesia. To the west of the area is the Ocean of Indonesia, to the east is Pondok Kelapa Village, to the north is Lais District, and to the south is Bengkulu City. The geographical points of the area are in the coordinates of $\mathrm{X}=57605$ to 59072 and $Y=1096505$ to 1095089 . It comprised the area of 250 hectares which consisted of $30 \%$ mineral and $70 \%$ peat soils.

\section{Sampling Methodology}

Soil random sampling was used as research design. The lowland area of 210 ha and upland area of 40 ha were sampled in random. The slope area was determined according to slope direction (upper, middle, and lower slopes according to Bureau of Soil Research, Bogor (Balittanah, 2004a,b,c 2005). The number of soil samples to represent the mineral and peat soil were 18 samples. The coordinate points of the soil samples are presented on Table 1.

There were four steps in the soil health assessment. They were soil obervation, scoring for soil performance indicators, laboratory analyses, soil health classification, and bioassay research for lettuce plant.

Step 1. Points for soil sampling on the field were determined according to Table 1. Soil performance indicators were observed and recorded on the Soil Health Assessment Forms. Soils were sampled in the depth of $0 \mathrm{~cm}$ to $20 \mathrm{~cm}$ using soil auger and were repeated 9 time with interdistance $50 \mathrm{~cm}$. All nine samples were mixed thoroughly in a big bucket, soil was separated from plant fragmentations, stones, and gravels to get a $2 \mathrm{~kg}$ soil composite.

Step 2. Scoring to each soil performance indicator on the field according to Table 2 was done by scoring 1 to the lowest soil performance indicator, and scoring 5 to the highest one. Every
Table 1. Coordinate points of sample soils.

\begin{tabular}{|c|c|c|c|}
\hline \multirow{2}{*}{$\begin{array}{l}\text { Code } \\
\text { No. }\end{array}$} & \multicolumn{3}{|c|}{ Coordinate } \\
\hline & UTM & $X$ & Y \\
\hline$\overline{\mathrm{PB} 3}$ & 48M 1911829595909 & 57824 & 1096164 \\
\hline PB4 & 48M 1909629596250 & 57605 & 1096505 \\
\hline PB5 & 48M 1910969596622 & 57740 & 1095609 \\
\hline PB13 & 48M 1917189595354 & 58359 & 1095609 \\
\hline PB14 & 48M 1914629595098 & 58103 & 1095353 \\
\hline PB16 & 48M 1912429595281 & 57883 & 1095536 \\
\hline PB9 & 48M 1920199594148 & 58658 & 1094439 \\
\hline PB 1 & 48M 1908089595228 & 57449 & 1095484 \\
\hline PB10 & 48M 1924329594835 & 59072 & 1095089 \\
\hline PB11 & 48M 1919269595872 & 58568 & 1096126 \\
\hline PB12 & 48M 1914239595757 & 58065 & 1096012 \\
\hline PB15 & 48M 1912939594720 & 57843 & 1094976 \\
\hline PB17 & 48M 1913529596224 & 57995 & 1096479 \\
\hline PB18 & 48M 1918419596399 & 58484 & 1096653 \\
\hline $\mathrm{PB} 2$ & 48M 1909369595562 & 57578 & 1095817 \\
\hline PB6 & 48M 1919559594942 & 58595 & 1095196 \\
\hline PB7 & 48M 1917689594758 & 58408 & 1095013 \\
\hline PB8 & 48M 1916879594243 & 58326 & 1094498 \\
\hline
\end{tabular}

indicator, then, was summed up to get total scores. Classing of soil health was determined according to the total score of the observed point of soil. All those soil properties were scored from 1 (to represent $<20 \%$ ) to 5 (to represent 100\%) (OSU Center 2009). In case of any soil property which was not included in that scoring criteria, the score was made and modified according to our reasonable purpose.

Step 3. Analysis of sample soil sample in the laboratory. The soil sample was air dried, grounded on mortal and pestled, and filtered until diameter $0.5 \mathrm{~mm}$ with ASTM screen. Soil sample was then ready for analyses. Soil chemical properties consisted of $\mathrm{pH}\left(\mathrm{H}_{2} \mathrm{O}\right)$, electrical conductivity (EC), total $\mathrm{C}$ and $\mathrm{N}$, available-P, base saturation (sum of cations of $\mathrm{K}, \mathrm{Ca}, \mathrm{Mg}$ devided by $\mathrm{CEC} \times 100 \%)$, and Aluminium saturation (Al devided by CEC $\times$ $100 \%$ ). Every soil chemical property was scored according to criteria from Bureau of Soil Research (Balittanah 2005) and presented in Table 3.

Step 4. Determining soil health class was based on the percentage of total scores of observed point of soil according to Table 4. The soil health was classified as Very Healthy, Healthy, Moderately Healthy, Less Healthy, and Unhealthy.

The $\mathrm{pH} \mathrm{H}_{2} \mathrm{O}$ (soil : distilled water $1: 2.5 \mathrm{w} / \mathrm{v}$ ), was measured by using $\mathrm{pH}$ meter (Conway). 
Table 2. Assessment criteria and the score for soil performance indicator on field.

\begin{tabular}{|c|c|c|c|c|c|}
\hline $\begin{array}{l}\text { Soil Performance } \\
\text { Indicator }\end{array}$ & $\begin{array}{l}\text { Very Low } \\
\text { (score 1) }\end{array}$ & $\begin{array}{c}\text { Low } \\
\text { (score 2) }\end{array}$ & $\begin{array}{l}\text { Moderate } \\
\text { (score 3) }\end{array}$ & $\begin{array}{c}\text { High } \\
\text { (score 4) }\end{array}$ & $\begin{array}{l}\text { Very High } \\
\text { (score 5) }\end{array}$ \\
\hline Soil Color & Red & Yellow & Green & Brown & Black \\
\hline $\begin{array}{l}\text { Soil Moisture } \\
\text { Content }\end{array}$ & $>75 \%$ & $<25 \%$ & $75 \%$ & $50 \%$ & $25-50 \%$ \\
\hline Slope & $>30 \%$ & $15-30 \%$ & $8-15 \%$ & $3-8 \%$ & $0-3 \%$ \\
\hline Texture & Sand/clay & Silty sand & Sandy clay & Silty clay & Clay Sapris \\
\hline Peat Maturity & Fibris & - & Hemis & - & \\
\hline Soil structure & Very hard & Hard & Less loose & Loose & Very loose \\
\hline Organic Matter & None & Small amount & Moderate & Large amount & Abundant \\
\hline $\mathrm{pH}\left(\mathrm{H}_{2} \mathrm{O}\right)$ & $<4.5$ & $4.5-5.5$ & $7.6-8.5$ & $5.5-6$ & $6-7.5$ \\
\hline $\begin{array}{l}\text { Earthworm } \\
\text { Population }\end{array}$ & none & $\begin{array}{l}\text { Small amount, } \\
\text { faeces, \& } \\
\text { earthworm } \\
\text { holes }\end{array}$ & $\begin{array}{c}\text { moderate, } \\
\text { faeces, \& } \\
\text { earthworm } \\
\text { holes }\end{array}$ & $\begin{array}{l}\text { Large amount, } \\
\text { faeces, \& } \\
\text { earthworm } \\
\text { holes }\end{array}$ & $\begin{array}{l}\text { Abundant, } \\
\text { Faeces, \& } \\
\text { earthworm } \\
\text { holes }\end{array}$ \\
\hline LCC & $<45 \%$ & $45-64 \%$ & $65-74 \%$ & $75-99 \%$ & $100 \%$ \\
\hline Soil Erosion & Big Gully & Small Gully & Gully & Sheet & None \\
\hline Soil Compaction & $\begin{array}{c}\text { Hard, } \\
\text { compact, bad } \\
\text { root } \\
\text { penetration }\end{array}$ & Hard, compact & $\begin{array}{c}\text { Firm, } \\
\text { Restricted } \\
\text { Root } \\
\text { Penetration }\end{array}$ & Loosely soil & $\begin{array}{l}\text { Freely Root } \\
\text { penetration }\end{array}$ \\
\hline $\begin{array}{l}\text { Vegetation } \\
\text { Performance }\end{array}$ & $\begin{array}{l}\text { White leaves, } \\
\text { stunted, } \\
\text { element stress }\end{array}$ & $\begin{array}{l}\text { Stunted, } \\
\text { element stress }\end{array}$ & $\begin{array}{l}\text { Plants grow } \\
\text { moderately, } \\
\text { less element } \\
\text { stress }\end{array}$ & $\begin{array}{l}\text { Leaves green, } \\
\text { no element } \\
\text { stress }\end{array}$ & $\begin{array}{l}\text { Leaves green, } \\
\text { normal } \\
\text { growth, no } \\
\text { element stress }\end{array}$ \\
\hline
\end{tabular}

Source: Bierman (2007) modified to fit to local area condition.

Table 3. Assessment criteria and scoring for soil analyses in the laboratory.

\begin{tabular}{lccccc}
\hline Soil Properties & $\begin{array}{c}\text { Very Low } \\
\text { (score 1) }\end{array}$ & $\begin{array}{c}\text { Low } \\
\text { (score 2) }\end{array}$ & $\begin{array}{c}\text { Moderate } \\
\text { (score 3) }\end{array}$ & $\begin{array}{c}\text { High } \\
\text { (score 4) }\end{array}$ & $\begin{array}{c}\text { Very High } \\
\text { (score 5) }\end{array}$ \\
\hline $\mathrm{C}(\%)$ & $<1$ & $1-2$ & $2-3$ & $3-5$ & $>5$ \\
$\mathrm{~N}(\%)$ & $<0.1$ & $0.1-0.2$ & $0.21-0.50$ & $0.51-0.75$ & $>0.75$ \\
$\mathrm{P} 2 \mathrm{O}$ 5 Bray $(\mathrm{ppm} \mathrm{P)}$ & $<4$ & $5-7$ & $8-10$ & $11-15$ & $>15$ \\
$\mathrm{KTK}\left(\mathrm{cmol}(+) \mathrm{kg}^{-1}\right)$ & $<5$ & $5-16$ & $17-24$ & $25-40$ & $>40$ \\
$\mathrm{Ca}\left(\mathrm{cmol}(+) \mathrm{kg}^{-1}\right)$ & $<2$ & $2-5$ & $6-10$ & $11-20$ & $>20$ \\
$\mathrm{Mg}\left(\mathrm{cmol}(+) \mathrm{kg}^{-1}\right)$ & $<0.3$ & $0.4-1$ & $1.1-2.0$ & $2.1-8.0$ & $>8.0$ \\
$\mathrm{~K}\left(\mathrm{cmol}(+) \mathrm{kg}^{-1}\right)$ & $<0.1$ & $0.1-0.3$ & $0.4-0.5$ & $0.6-1.0$ & $>1.0$ \\
Bases saturation $(\%)$ & $<20$ & $20-40$ & $41-60$ & $61-80$ & $>80$ \\
$\mathrm{Al}$ saturation $(\%)$ & $<5$ & $5-10$ & $11-20$ & $20-40$ & $>40$ \\
DHL $\left(\mathrm{dS} \mathrm{m}^{-1}\right)$ & $<1$ & $1-2$ & $2-3$ & $3-4$ & $>4$ \\
\hline
\end{tabular}

Source: Balittanah (2005).

Electrical Conductivity (EC) was measured by using proportion (soil : distilled water $=1: 1$ ), was measured by using EC meter (Jenway). Carbon total was measured using Walkley and Black Method. Nitrogen was measured by using Kjeldhal method. Available-P $\left(\mathrm{P}_{2} \mathrm{O}_{5}^{-}\right)$was extracted by using Bray 1 method and analysed using UV-Vis Spectrofotometer (PG Instrument Ltd.). Exchanged-base (K-, Ca-, and $\mathrm{Mg}$ - exchangeable) was extracted by using $1 \mathrm{~N}$ Ammonium Acetic $\mathrm{pH}$ 7 , and exchangeable- $\mathrm{K}$ was measured by using Flamephotometer, Calsium (Ca-exc) and 
Tabel 4. Assessment criteria indicators for lettuce plant.

\begin{tabular}{lccccc}
\hline \multirow{2}{*}{ Growth Indicators } & \multicolumn{5}{c}{ Score } \\
\cline { 2 - 6 } & 1 & 2 & 3 & 4 & 5 \\
\hline Plant height $(\mathrm{cm})$ & $0-6 \mathrm{~cm}$ & $7-12 \mathrm{~cm}$ & $13-18 \mathrm{~cm}$ & $19-24 \mathrm{~cm}$ & $25-30 \mathrm{~cm}$ \\
Degree of leaf greenness & $0-8$ & $9-16$ & $17-24$ & $25-32$ & $33-40$ \\
Shoot/root ratio (\% relative) & $0-20 \%$ & $21-40 \%$ & $41-60 \%$ & $61-80 \%$ & $81-100 \%$ \\
Number of leaves & $0-2$ & $3-4$ & $5-6$ & $7-8$ & $>8$ \\
Plant fresh weight (g) & $0-20 \mathrm{~g}$ & $21-40 \mathrm{~g}$ & $41-60 \mathrm{~g}$ & $61-80 \mathrm{~g}$ & $>80 \mathrm{~g}$ \\
\hline
\end{tabular}

Magnesium (Mg-exc) were measured by using a titrated method with $0.005 M$ EDTA. Aluminium and Hidrogen were extracted with $1 \mathrm{~N} \mathrm{KCl}$ and measured by using titrated method with $0.1 \mathrm{NH}_{2} \mathrm{SO}_{4}$ standard.

Data of soils assessment were plotted and the total scores were used to categorized the soil health into one of the five categories (e.g. Unhealthy, Less healthy, Moderate healthy, High healthy, and Very healthy). To compare the soil performance indicators and lettuce plant indicators, data of the two observations were analyzed using t-test 0.05 . If the result was significant, it means the assessment method can not be applied so another method should be introduced.

\section{RESULTS AND DISCUSSION}

The topography of research area were flat land with total area of 210 ha and light slope with total area of 40 ha. The peat type area covered $70 \%$, whereas mineral type area covered $30 \%$. The land use of flat peat soil area was dominated by paddy. Palm oil plantation was commonly found on slopy mineral soil. The peat soil in this area was unique because it was not influenced by tidewater, mainly consisted of woody remains especially from angiosperm, and originated from the in situ formation with topogenic peat as the result of slope effect that supplied mineral soil materials to the peat area. The spread of peat downstream usually reached $10-50 \mathrm{~km}$ from the sea line (Ritung and Wahyunto 2003).

Table 5 showed that the area was classified as a moderate healthy and a healthy based on the 12 indicators observed in the field. Three soil samples of each mineral soils and peat soils, which represented a moderate healthy and a healthy soil, respectively, were analyzed in the laboratory for soil chemical properties. Result of laboratory analysis were more accurate than field observations but laboratory procedure took a longer time. Field analyses could be reliable method and more practical especially for farmers. But the farmers should be trained so they get used to assess soil indicator performances.

Soils with category Moderate Healthy were obtained from PB5 and PB12 (mineral soils) and PB6 (peat soil). Healthy soils were PB 7 (mineral) and PB13 as well as PB14 (peat soils). Following field observations and categorization, soil measurement was continued to laboratory analyses. It was an important step since field categorization was greatly depended on the accuracy of person (s) during the observations. Inspite of this fact, both field and laboratory works are interdependent to get the whole picture of soil status.

Table 6 showed that soil chemical properties of the soil samples were categorized as healthy except on bases saturation which showed a very low level. It means the availability of the nutrition elements to plants was low. The unavailability of the elements was due to the low capacity of soil to hold and to exchange the elements. This was indicated by the observed data that the CEC of mineral and peat soils were low. The soil had low $\mathrm{pH}$ indicated that it was acid soil, and it was also another factor that imposed the low availability of nutrient elements. Eventhough the C-organic of the peat soil was very high (score 5), it was not strong enough to support the CEC, bases saturation, and to ameliorate high $\mathrm{Al}$ saturation.

Table 7 indicated that 3 variables of growth of lettuce plants (plant height, leaf greenness, and number of leaves) were in category healthy, while shoot/root ratio was very low and plants fresh weights were varies. Total categories, lettuce plants were in moderate and healthy categories and this had no correlation to the results from soil performance indicators. It was supported from the t-test showing that it fitted the significancy of $95 \%$.

The balance among soil physical, chemical, and biological properties will contribute the assurance of soil health in the future. For that reason, soil health asessment needs some indicators such as physical, chemical, and biologcal properties 


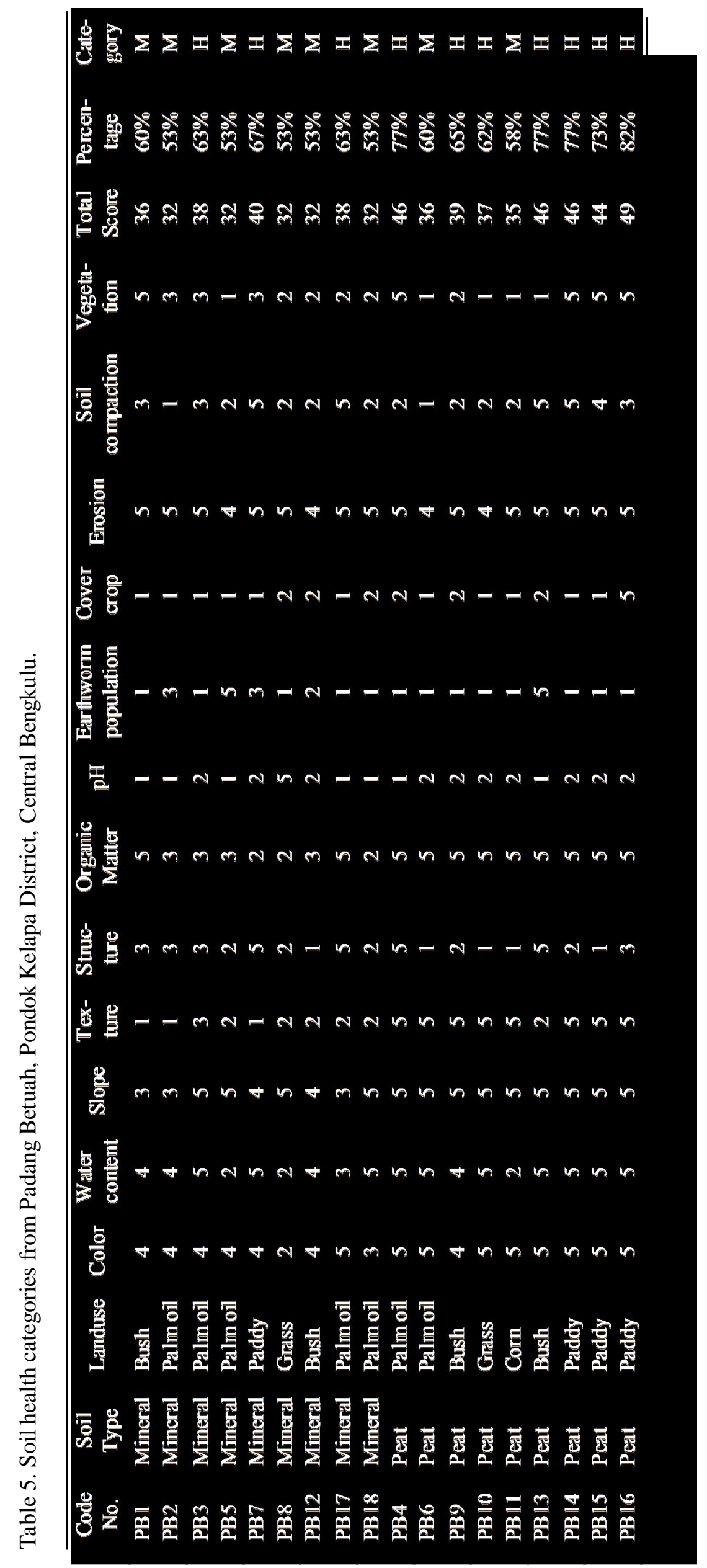




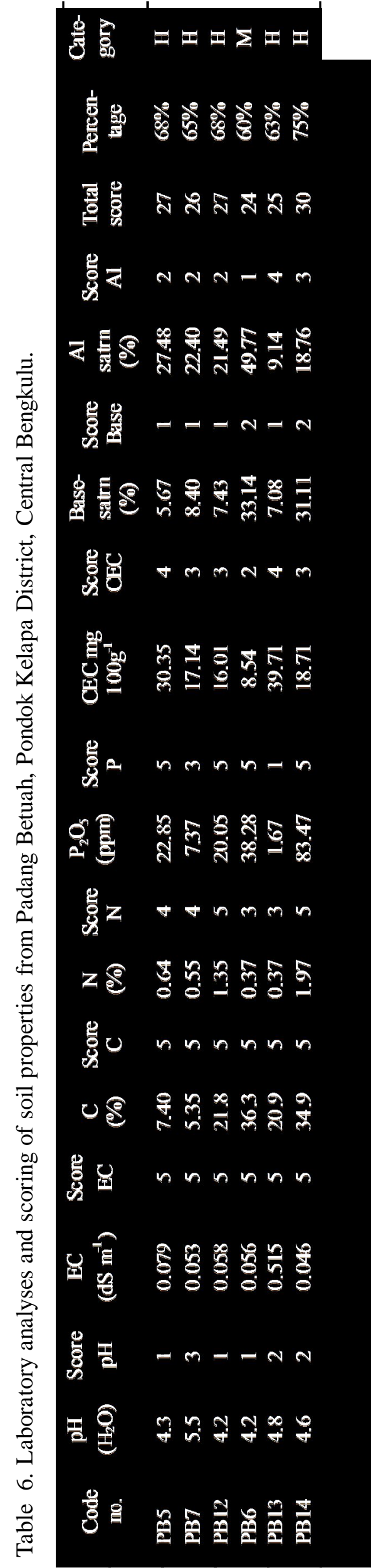

$$
\begin{aligned}
& \text { 总 } \Sigma \Sigma \pm \pm \Sigma \pm \\
& \text { 章 }
\end{aligned}
$$

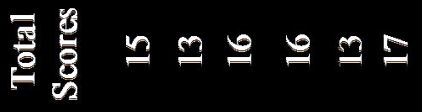

$$
\begin{aligned}
& \text { 兽 } m-N m-\& \\
& \text { 憙营 } \\
& \text { 器 } n n n n n n \\
& \text { 퐁 昰 } \\
& \text { 总 }-----
\end{aligned}
$$

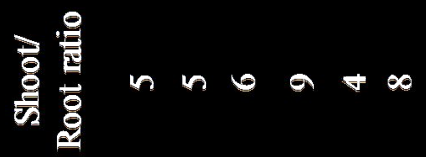

$$
\begin{aligned}
& \text { 若 } m m n m m \neq
\end{aligned}
$$

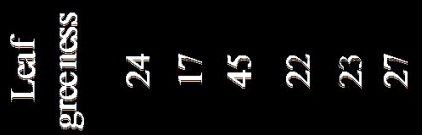

$$
\begin{aligned}
& \text { 总 } m m m \neq m
\end{aligned}
$$

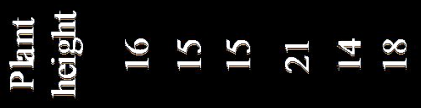

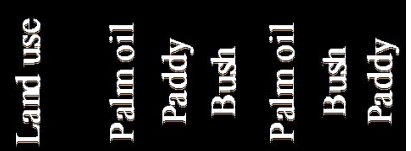

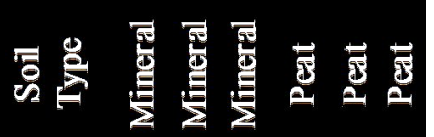

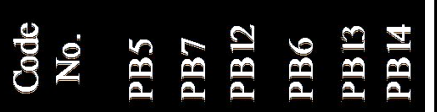

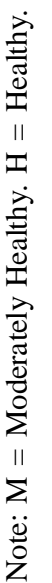


(Monkiedje et al. 2006). Eventhough there were 12 soil health indicators used in this research, more indicators were also used by other researchers. Another researcher used 39 soil health indicators consisted of 16 physical indicators, 11 chemical indicators, and 12 biological indicators (Idowu et al. 2008). The number of soil indicators used in the asessment depends on the location and level of accuracy in measuring soil health (Kinyangi 2007). Furthermore, it is impossible to choose a single indicator to measure soil health, but it must be chosen some relevant indicators and also having close relationship with the problem of measured soil. For example, the dominant soil health criteria on post-mining areas are soil structure, soil moisture, soil organic matter, soil $\mathrm{pH}$, and number of soil earthworms. On unfertile soil the main criteria are the level of soil elements and soil organic matter. Another example is health-degraded soil which is measured for the level of soil erosion, soil organic matter, soil structure, and soil $\mathrm{pH}$. The soil asessment method used in this research can be applied on every soil type including agricultural land, mineral soil, peat soil, post-mining soil, less fertile soil, marginal soil, degrade soil, and other various soil landuses.

\section{CONCLUSIONS}

It can be concluded that the assessment of soil health using soil performance indicator approach, both on field (qualitative, quick, and less accurate) and laboratory approach (quantitative, time consuming, and accurate) was reliable. The categories of Padang Betuah soils were moderate healthy and healthy. The responses of lettuce plants upon the types of soils were $95 \%$ in the interval of confidence, but no correlation indicated between soil health performance method and plant performance. It showed that soil health categories based on lettuce growth variables did not correlate to soil health categories based on soil performance indicators. Further research is needed for other different types of soils so that soil health assessment method could be applied on soil types in this area.

\section{ACKNOWLEDGEMENTS}

We appreciate for all kind helps of friends, students, the laboratory analists and staffs of Soil Laboratory and Agronomy Laboratory, Agriculture Faculty, University of Bengkulu. Special thanks are regarded to M. Faiz Barchia, Leonardo Arlan,
Lodi Sihaloho, Suroto, Mansyur, Dedy, and Suyono. We also have a great regard to DGHE (DP2MDIKTI) Jakarta for the support research funding through National Strategic Research Grant - 2009 and University of Bengkulu.

\section{REFERENCES}

Balittanah [Bureau of Soil Research]. 2004a. Pengambilan Contoh Tanah Untuk Analisis Sifat Fisika Tanah. Pusat Penelitian dan Pengembangan Tanah dan Agroklimat, Bogor (in Indonesian).

Balittanah [Bureau of Soil Research]. 2004b. Pengambilan Contoh Tanah Untuk Uji Tanah. Penelitian dan Pengembangan Tanah dan Agroklimat, Bogor. Bogor (in Indonesian).

Balittanah [Bureau of Soil Research]. 2004c. Prosedur Pengambilan Contoh Tanah Untuk Analisis Mikroba. Penelitian dan Pengembangan Tanah dan Agroklimat, Bogor (in Indonesian).

Balittanah [Bureau of Soil Research]. 2005. Petunjuk Analisis Tanah, Air, Pupuk, dan Tanaman. Penelitian dan Pengembangan Tanah dan Agroklimat, Bogor (in Indonesian).

Bierman P. 2007. Ohio Soil Health Card. Centers at Piketon, Ohio State Univ. http://www.ag.ohiostate.edu/-pre. Assecced on October 5, 2010.

Gugino BK, OJ Idowu, RR Schindelbeck, HM van Es, DW Wolfe, JE Thies and GS Abawi. 2007. Cornell Soil Health Assessment Training Manual, Edition 1.2, Cornell University, Geneva, NY, 59 pp.

Hocking PJ. 2001. Organic acids exuded from roots in phosphorus uptake and aluminum tolerance of plants in acid soils. Adv Agron 74: 63-97.

Idowu OJ, HM van Es, GS Abawi, DW Wolfe, JI Ball, BK Gugino, BN Moebius, RR Schindelbeck and AV Bilgili. 2008. Farmeroriented assessment of soil quality using field, laboratory, and VNIR spectroscopy methods. Plant Soil 307 (1-2): 243-253. DOI:10.1007/ s11104-007-9521-0.

Kinyangi J. 2007. Soil Health and Soil Quality: A Review. worldaginfo.org/files/Soil $\% 20$ Health\% 20Review.pdf. Dec 8, 2010.

Monkiedje A, M Spiteller, D Fotio and P Suku. 2006. The effect of land use on soil health indicators in Peri-Urban Agriculture in the humid forest zone of Southern Cameroon. J Environ Qual 35: 24022409. DOI:10.2134/jeq2005.0447.

Nelson KL, DH Lynch and G Boiteau. 2009. Assessment of changes in soil health throughout organic potato rotation sequences. J Agric Ecos Environ 131: 220228.

NRCS [Natural Resources Conservation Service]. 1996. Indicators for Soil Quality Evaluation. http:// soils.usda.gov/sqi/publications/files/sq-2.pdf accessed on October 5, 2010.

OSU [Ohio State University] Center. 2009. Ohio Soil Health Card. OSU Centers at Piketon: Piketon 
Research \& Extension Enterprise Center, OHIO. http://www.ag ohio-state deu/-prec, Accessed on October 5, 2010.

Ritung S and Wahyunto. 2003. Kandungan Karbon Tanah Gambut di Pulau Sumatera. Workshop on Wise Use and Sustainable Peatlands Management Practices,
October $13^{\text {th }}-14^{\text {th }}, 2003$, Hotel Pangrango II, Bogor: 1-16 (in Indonesian).

Riwandi. 2007. Kualitas Tanah. Bahan Ajar Program Studi Ilmu Tanah Jurusan Budidaya Pertanian Fakultas Pertanian UNIB, 65 p (in Indonesian). 